Revue

de Sémantique

et Pragmatique
Revue de Sémantique et Pragmatique

40 | 2016

Exclamation et intersubjectivité

\title{
On the Pragmatics of Interjections in Parliamentary Interruptions
}

\section{Naomi Truan}

\section{(2) OpenEdition \\ 1 Journals}

\section{Electronic version}

URL: http://journals.openedition.org/rsp/323

DOI: $10.4000 /$ rsp.323

ISSN: 2610-4377

\section{Publisher}

Presses universitaires d'Orléans

\section{Printed version}

Date of publication: 1 March 2017

Number of pages: 125-144

ISSN: 1285-4093

\section{Electronic reference}

Naomi Truan, "On the Pragmatics of Interjections in Parliamentary Interruptions », Revue de

Sémantique et Pragmatique [Online], 40 | 2016, Online since 01 March 2018, connection on 30 April 2019. URL : http://journals.openedition.org/rsp/323 ; DOI : 10.4000/rsp.323 


\title{
On the Pragmatics of INTERJECTIONS IN PARLIAMENTARY INTERRUPTIONS
}

\author{
Naomi Truan \\ CeLiSo (EA 7332), Université Paris-Sorbonne
}

Interruptions in parliamentary debates are a powerful way of disturbing the speech of the legitimate speaker while conveying ideas, mostly in a brief form. Based on a corpus of eighteen parliamentary debates at the German Bundestag between 1998 and $2015^{1}$ which enables to notice continuities and instabilities throughout various political formations, this article intends to offer a renewed perspective on interruptions by conducting research on a particular form of interruption which has so far drawn little attention: interjections. In comparison with other types of interruptions, interjections play a special part in parliamentary encounters, since they are syntactically autonomous and semantically complete communicative events.

This paper aims at a better understanding of interjections in a formal environment where various levels of addressees are at stake. Focusing on the speaker's point of view and integrating the role of the addressees - as well the present ones during the plenary sessions as the 'imagined' ones constituted by journalists and citizens -, I argue that interjections constitute a special type of interruption due to their interactive nature.

The paper is structured as follows. I begin by presenting interruptions in parliamentary debates as well as the corpus and methodology used in this paper. After explaining why interjections may be treated as a special type of interruptions, I analyse the two main functions of interjections. In Section 3, I pursue the characterisation of interjections, defining them as approval markers. This

1 The corpus and its detailed documentation are freely available online: $\underline{\text { hdl.handle. }}$ net/11403/de-parl. 
leads me to consider the dialogical nature of interjections in relation with the addressees of parliamentary discourse.

\section{INTERRUPTIONS IN PARLIAMENTARY DEBATES: A FREQUENT DEVIATION TO}

\section{THE NORM}

In Section 1, I show that despite their perceived deviating features, interruptions are constitutive of parliamentary debates (1.1). I then introduce the methodology used to identify and enumerate interruptions in parliamentary debates (1.2).

\subsection{INTERRUPTIONS AS DISRUPTIVE, NONETHELESS ITERATIVE COMMUNICATIVE EVENTS}

Interruptions have first been described from a conversational-analytic perspective as disruptions of the turn-taking-system (Sacks, Schlegoff \& Jefferson 1974; Carbó 1992:25). In this perspective, interruptions differ from overlaps, where hearer(s) and speaker(s) might speak at the same time without willingly wanting to break the words' flow of their communication partner. This distinction appears to be irrelevant in parliamentary encounters, where speech roles are strictly coordinated, so that no interruption can be considered as a defective assessment of the current speech situation. I speak of 'interruption' or 'interrupting pattern'2 every time a non-legitimate speaker intervenes in the formal talk of another Member of Parliament (henceforth MP) without being invited to, that is when an MP takes an intrusive role in order to modify or determine events or their outcome. 'Questions' (Zwischenfragen) and 'short interventions' (Kurzinterventionen) are not interrupting patterns, since they have to be expressly allowed by the President of the Bundestag (Hitzler 1990:622).

Due to the challenge they pose to the legitimate MP in the spotlight, interruptions in parliamentary encounters are described as "the salt in the soup" (Burkhardt 2004:1 [my translation]). Although numerous studies have examined interruptions in parliamentary debates (Kühn 1983; Carbó 1992; Bonnafous \& Desmarchelier 1999; Van der Valk 2000; Burkhardt 2004; Bevitori 2004; Shenhav 2008), they rarely combine qualitative and quantitative methods over the years and generally focus on a particularly heated debate. In my corpus, apart from isolated discursive sequences, the average number of interruptions per debate at the Bundestag is 69,5 (1251 interruptions across eighteen debates).

${ }^{2}$ The word 'heckling' can sometimes be found in place of 'interruption'. Since 'heckling' can be defined as "the practice of calling out comments to interrupt a person making a speech" (Collins Dictionary online, 26.12.2016), I consider it to take part in interrupting patterns, without subsuming them, since interruptions do not necessarily involve 'comments' (see below). 
Interruptions remain relatively infrequent and do not result in "systematic disruption of speeches" as noticed by Shenhav (2008:124) at the Knesset, or in "discursive harassment" (Bonnafous \& Desmarchelier 1999:94), as is sometimes the case at the French Assemblée Nationale. Although interruptions do not disrupt the monological structure of authorised parliamentary talks, they are a recurring pattern in the plenary debates on Europe that constitute my corpus. Albeit tightly regulated and monitored by the parliamentary rules, interjections contribute to the perceived immediacy and authenticity of parliamentary encounters. They thus lie at a crossroads between shared expectations and search for novelty. I argue that a fine-grained typology of interjections is possible.

\subsection{FOR A TYPOLOGY OF INTERRUPTIONS IN PARLIAMENTARY DISCOURSE}

Interruptions cannot be attached to a unique lexical-grammatical category. This considerable diversity highlights the necessity to draw a typology based on pragmatic functions rather than morpho-syntactic markers. Interruptions combine brevity and noticeability. First, they are usually not longer than ten words (not necessarily limited to one sentence). Secondly, interruptions are performed with a loud voice, preferably intelligibly, so that not only the legitimate speaker and other present MPs can hear them, but also the stenographers ${ }^{3}$. The analysis is based exclusively on transcribed interruptions from the German parliamentary recordings, and, after a first inventory, on video recordings. Despite their acknowledged limitations (Olschewski 2000), the Bundestag transcriptions are very detailed and precise. My hypothesis is thus that even though some of the interruptions are not transcribed, the transcribed ones constitute key moments of the debates - moments that are deemed necessary to mention in the official transcript. Furthermore, the quality of the video recordings, which focus on the speaker at stake, does not necessarily allow for a perfect and exhaustive transcription of all interruptions.

Within the different types of the 1251 interruptions of my corpus, six categories can be delineated from a pragmatic perspective based on speech acts ${ }^{4}$ : (1) approval; (2) attack; (3) comment; (4) interjection; (5) question; and (6) request. These various categories explain why I find it more appropriate to use the term 'interruptions' or the expression 'interrupting patterns' instead of 'unauthorized interruptive comments' (Zima, Brône \& Feyaerts 2010). Indeed, not every interruption can be seen as a comment. In this article, I focus only on interjections as a subcategory of interruptions. Despite substantial research on interrupting patterns in parliamentary discourse, interjections as a particular type of inter-

${ }^{3}$ For an overview of transcribing praxes by the stenographers, see Burkhardt (2004: 41-46).

${ }^{4}$ See Ehlich (1986:23) for the association of interjections with illocutionary acts. 
ruption still remain the poor relation of parliamentary encounters ${ }^{5}$. Therefore, the purpose of the present article is to assess the specificity of interjections within interrupting patterns at the German Bundestag.

\section{SPECIFICITIES OF INTERJECTIONS AMONGST INTERRUPTIONS}

This section addresses the identification problems raised by interjections and details how interjections were counted up. First, the distinction drawn in the typology of interruptions between the categories 'approval' and 'interjection' is examined more carefully (2.1). From a morpho-syntactic perspective, interjections are described as brief and sentence-equivalent markers. This definition is in line with competing views on their semantic properties: do interjections encode meaning (2.2)? Attributing a stable semantic content to interjections is indeed a hard task, but it is nonetheless possible to say that they function as expressive markers (2.3). Despite their apparent spontaneity, interjections are highly conventionalised communicative events closely associated with the multiple audiences of parliamentary debates (2.4).

\subsection{CLASSIFICATION ISSUES: INTERJECTIONS AND APPROVAL MARKERS}

Compared to the five other classes of interruptions (see 1.2), interjections form a non-consistent class, thus presenting acute identification problems. In line with Rosier (2000:20) and Cuenca (2000:36), I argue that interjections are not a closed class of words and that every word can potentially become interjectional. Therefore, one of the main difficulties regarding interjections is the possibility to classify them into other categories of interruptions according to their semantic-pragmatic value, and especially the collusion with the first category ('approval'). Interjections expressing agreement like Ja! ("Yes!") or Genau! ("Right!") were first classified as approval markers, but then also taken into account as interjections for the analysis. Among approval markers, only short forms such as those aforementioned have been considered as interjectional, contrary to enriched forms such as Sehr richtig! ("Very correct!") or Sehr wohl! ("Certainly!" / "Very good!"). Indeed, this structure already shows a relative degree of sentence construction with the introduction of a modifier.

115 interruptions have been classified as approval markers. Among them, 42 are both approval markers and interjections. These 42 occurrences have been integrated into the analysis of interjections. Irrespective of the specific

${ }^{5}$ Although Shenhavs article (2008) is entitled "the case of repeated interjections to Rabin's speeches in the Israeli parliament", it actually deals with interruptions and not with interjections specifically (or, rather, it implicitly defines interjections as the act of interjecting, i.e. of interposing abruptly or sharply, interrupting with, and not in the restricted linguistic sense). Burkhardt (2004) addresses interjections, but not on a systematic basis. 
issue of the category 'approval', 89 other interjections have been recorded. This amounts to 131 interjections, that is $10,47 \%$ of the total number of interruptions (1251) in the corpus. Interjections indeed constitute only one of the many resources used as a means to confront one's position with that of the legitimate speaker in the parliamentary discursive battleground. Compared to the other five interrupting patterns, interjections are quantitatively less significant. On the other hand, comments (i.e. full sentences with correcting or adding value) represent $49 \%$ of the interruptions (613 occurrences). Nevertheless, interjections occur approximately as often as requests $(9,75 \%, 122$ occurrences) and questions $(12,71 \%, 159$ occurrences), as Figure 1 shows:

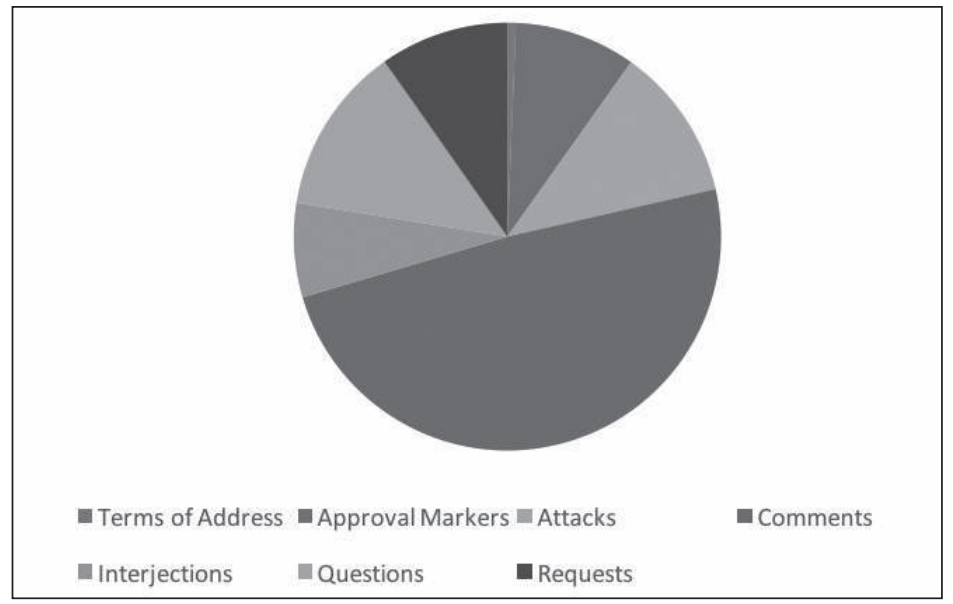

Figure 1: Distribution of Interruptions according to Speech Act

\subsection{INTERJECTIONS FROM A SYNTACTIC-SEMANTIC PERSPECTIVE}

Interjections are syntactically autonomous communicative events (Cuenca 2000:32), mostly expressed in a brief form. Interjections function as sentences or sentence-equivalents (Cuenca 2000:30; Caron-Pargue \& Caron 2000:53). In this paper, I precisely focus on interjections within interruptive patterns appearing isolated, that is without any further sentence from the speaker. As Wharton observes, "[o]ne point of agreement [...] is that: an interjection is capable of constituting an utterance by itself in a unique, non-elliptical manner" (2000:176). Based on the criterion of brevity mentioned for interruptions, interjections can be considered as the most prototypical markers of the category. Their brevity makes them particularly interesting forms of interruptions, since they "let the speaker express the basic information that he [or she] wants to convey with the minimum linguistic effort" (Cuenca 2000:36).

The conciseness of interjections makes it particularly tricky to link them with an identifiable speaker: in 32,06\% of the cases (42 occurrences out of 131 
interjections), the official transcript of the Bundestag had to indicate the name of the party and not that of the MP. It means that the stenographers have been able to localise the origin of the interjection, but not its unequivocal source. By way of comparison, out of the 1251 interruptions, 144 interruptions $(11,51 \%)$ could not point to a referable source. This shows that interjections are three times more susceptible to difficulties regarding narrow speaker's identification.

The conciseness and the syntactic independence of interjections have led some linguists to reflect upon the possibility for interjections to have a conceptual meaning. On the one hand, Ameka (1992a, 1992b), Wierzbicka (1992) and Wilkins (1992) argue that interjections are "semantically rich and have a definite conceptual structure which can be explicated" (Wilkins 1992:120). On the other hand, interjections are described as having no conceptual meaning (Wharton 2000), lacking referential content, and are considered to encode pragmatic meaning more than a lexical one (Cuenca 2000:32, 35). Goffman goes further, claiming that interjections are a "ritualised act" (1981:100) which should be analysed as a socio-communicative event rather than for the semantic characteristics they might have.

Without rejecting Wharton's claim (2000), Padilla Cruz shows that "it poses some problems in those cases in which interjections stand alone as full utterances, without any preceding or following proposition. In such cases, no attitude can be projected toward any embedded propositional content because there is obviously no propositional content to embed" (2009a:186). Despite their high context-dependency, I argue that interjections in parliamentary debates are to be associated with a minimal semantic content that reflects the state of mind of the utterer.

\subsection{INTERJECTIONS AS EXPRESSIVE MARKERS}

In my corpus, interjections are overwhelmingly linked with exclamations - and consequently very often followed by an expression mark when written (Wharton 2000:176) -, even though they are in no ways equivalent (see Rosier 2000:22). As explained by Padillaz Cruz (2009a:182) (in line with Ameka 1992a:106), individuals use them "to express their mental states, attitudes or reactions to perceived stimuli". Their lack of stable semantic value indicates the speaker's state of mind but not its exact content, thus leaving a vast array of interpretations, even in a priori unambiguous cases like Ja! ("Yes!") or Nein! ("No!"), as Section 3 will show. From this (commonly accepted) point of view, interjections are expressive markers. Louis-Marie de Lahaye de Cormenin, a French jurist and political pamphleteer, ironically noticed "the call of passion" in the 19th century, claiming that "speaking interrupters" verify whether stenographers have recorded their "monosyllables and interjections", so that MPs 
can pretend to "accomplish [their] legislative mandate with dignity [by uttering only interjections]" (Cormenin 1837:320 [my translation]). By using the expression "speaking interrupters" who do not "want to let the parliamentary session go without saying something", Cormenin acknowledges a verbal status to interjections, a position consistent with current research on interjections. Although one might have thought that interjections are instinctive or uncontrolled linguistic signalisations, they are in fact very conventionalised (Ameka 1992a:106) since they are language specific (Caron-Pargue \& Caron 2000:52) and 'involve the speakers' conscious evaluation of the spatio-temporal setting or the selection of an item from among a more or less wide set of possible candidates for what they want to express" (Padilla Cruz 2009a:182-183).

\subsection{INTERJECTIONS AS CONVENTIONALISED MARKERS}

The conventionalised nature of interjections happens to be particularly true for the formal setting of plenary debates, where interjections as a subtype of interruption function as markers of support or discontent rather than expressions of immediate emotions. In a political context, interjections convey political meaning in a nutshell. Rosier speaks in this sense of an "orchestration of the speaker's emotions", which should be understood as "addressed to someone" in a "situation of interlocution" (2000:23).

Interjections are multiple oriented towards the other MPs, but also towards the citizens; this becomes clear once the distinction between the addressees (allocutaires) and the target recipients (destinataires) of parliamentary debates is made more systematically (Ducrot 1980). Whereas addressees are linguistically prototypically encoded by terms of address, imperative forms and second person pronouns, the participants actually addressed based on the propositional content of the utterance and its illocutionary force are target recipients. Both are discursive roles and should be distinguished from the real persons (hearers or auditeurs), as the speaker (locuteur) is not equivalent to the speaking subject (sujet parlant).

In most cases of everyday conversations, addressee(s) and target recipient(s) correspond to each other. Nonetheless, in parliamentary encounters, an utterance can be formally addressed to a colleague and actually intended to other colleagues (as well) and/or to a broader audience. Interjections, which convey an impression of expressivity, spontaneity and authenticity, as in a 'genuine' dialogue (even though their natural character is construed), play an important part in designing multiple levels of reception since they "directly organize the partners' verbal interaction" by "establishing a direct relation between speaker and listener in discourse" (Meng \& Schrabback 1999:1264). 


\section{INTERJECTIONS AS APPROVAL MARKERS}

Section 3 focuses on interjections expressing approval. As previously shown, 42 interjections are approval markers, that is $32,06 \%$ of all interjections. The support function of interjections is therefore the most salient one. Contrary to common sense, numbers indicate that interjections as approval markers are not primarily used towards in-group members (3.1). These findings cast doubt on the actual support function of interjections (3.2) and demonstrate that interjections mostly function as phatic markers (3.3).

\subsection{DISTRIBUTING SUPPORT BETWEEN THE MAJORITY AND THE OPPOSITION}

Interjections in parliamentary debates constitute a relative limited class of 35 different words, which shows a certain consistency in the use of interjections within interruptions. Notwithstanding this finding, 14 interjections are hapax, which also indicates that conventionalised interjections cohabite with more creative ones. Amongst the most standardised interjections, approval markers are the most frequent: Ja! / Oh ja! / Aber ja! (“(Oh) yes!”) appears 15 times (11,45\% of all interjections) and Richtig! (“Right!”) occurs 19 times (14,5\%): a quarter of the interjections are expected and ritualised. Since these interjections are secondary ones ${ }^{6}$, their meaning can be inferred from the meaning of the lexemes $j a$ and richtig when not used as interjections. Therefore, their semantic value is not disputed and expresses agreement, support and encouragement ${ }^{7}$.

Surprisingly, interjections as approval markers are not primarily directed towards in-group members with the same political affiliation. Despite all expectations, interjections as approval markers are not mainly used amongst similar political parties. Interjections are actually addressed to out-group members, i.e. to opposition members:

${ }^{6}$ Secondary interjections "are those words which have an independent semantic value but which can be used as utterances by themselves to express a mental attitude or state" (Ameka 1992a:111).

7 The closed list of interjections marking approbation consists of only four different markers: Genau! / Genau so! ("Exactly!”) [5 occurrences]; Ja! / Oh ja! / Aber ja! (“(Oh) yes!”) [15 occurrences]; Jawohl! (“Absolutely!”) [3 occurrences]; Richtig! (“Right!”) [19 occurrences]. 


\begin{tabular}{|l|l|l|}
\hline $\begin{array}{c}\text { Positioning of the interrupting / } \\
\text { interrupted MPs }\end{array}$ & $\begin{array}{c}\text { Number of } \\
\text { occurrences }\end{array}$ & $\begin{array}{c}\text { Percentage of } \\
\text { occurrences }\end{array}$ \\
\hline Majority / Majority & 2 & $4,76 \%$ \\
\hline Majority / Opposition & 10 & $23,81 \%$ \\
\hline Opposition / Majority & 14 & $33,3 \%$ \\
\hline Opposition / Opposition & 16 & $38,1 \%$ \\
\hline Total & 42 & $100 \%$ \\
\hline Positioning of the interrupting / & Number of & Percentage of \\
occurrences & $42,86 \%$ \\
\hline Within the same group & 18 & $57,14 \%$ \\
\hline Towards the other group & 24 & $100 \%$ \\
\hline Total & 42 & \\
\hline
\end{tabular}

Table 1: Distribution of interjections as approval markers according to the variable majority / opposition

As Table 1 shows, more than half of the occurrences $(57,14 \%)$ are aimed at the out-group. This figure contradicts the idea that interjections as approval markers express agreement: why would MPs strengthen the utterances of their opponents more than the utterances of their own parliamentary group? Hence, a more fine-grained distinction based on the pragmatic context is crucial.

\subsection{TENSIONS BETWEEN IN-GROUP AND OUT-GROUP MEMBERS}

Whereas interjections indicating approval are very uncommon within the ruling majority (only two occurrences), they serve the legitimation process of opposition parties (sixteen occurrences):

(1) Dr. Gerd Müller (CDU) [opposition]: Frau Merkel hat bereits darauf hingewiesen und es verdeutlicht - ich bin ebenfalls fest davon überzeugt -: Europa braucht eine Identität,

Peter Hintze (CDU) [opposition]: Jawohl!

G.M: eine kulturelle Grundlage, eine gemeinsame Wertebasis. (DE 2002.12.19) ${ }^{8}$

G.M: Mrs Merkel already mentioned and exemplified it - I am also convinced of that -: Europe needs an identity,

P.H: Absolutely!

G.M: a cultural foundation, a common set of basic values.

Within the same party, interjections tend to strengthen in-group identity, showing support towards the legitimate speaker, but more generally to the party

8 The format of the files is indicated as follows: the two-letter ISO code (ISO 3166 alpha-2) of the country's name, year, month and date of the plenary debate at the German Bundestag. 
itself: Gerd Müller does not only formulate a personal belief, but relies on a shared, not contentious assumption. Indeed, the enunciative source of the utterance "Europe needs an identity", Mrs Merkel, is an authority figure. The reverse scenario (a MP from the parliamentary opposition greeting a MP from the majority) is also possible:

(2) Dr. Friedbert Pflüger (CDU) [opposition]: Deshalb bitte ich Sie, uns hier nicht zu verunglimpfen und zu behaupten, wir wollten antieuropäische Gefühle hervorrufen oder die Türkei ausgrenzen.

Zuruf vom BÜNDNIS 90/DIE GRÜNEN [majority]: Ja! (DE 2003.06.26)

F.P: This is why I ask you not to denigrate and not to claim that we want to arouse anti-European feelings or to exclude Turkey9.

Interruption from the Green party: Yes!

The interpretative value of the interjection in this occurrence is ambiguous. First, the interjection functions as a recognising signal and, therefore, as a phatic marker: the Greens show that the referential scope of the prototypical address pronoun Sie ("you") has been understood; they feel addressed. Secondly, the Greens assess the propositional content "I ask you not to denigrate and not to claim that we want to arouse anti-European feelings or to exclude Turkey" by manifesting "their mental states, attitudes or reactions to perceived stimuli" (Padilla Cruz 2009a:182). One can either interpret the interjection as a genuine marker of empathy ("We take your request into consideration and will not say anymore that you are arousing anti-European feelings") or - and this is more likely - as an ironic marker ("We say 'yes' to indicate that we have heard you, but we don't care"). The interjection "Yes!" operates as an antiphrasis conveying an opposite signification from the generally accepted meaning.

\subsection{MESSAGE RECEIVED... BUT CERTAINLY NOT APPROVED}

Interjections from opposition members towards majority members do not primarily mark approval, but signal that the utterance has been perceived and received. This is particularly pregnant when terms of address are employed:

(3) Joseph Fischer (BÜNDNIS 90/DIE GRÜNEN) [majority]: Nun wird der Bundesregierung vorgehalten: Ihr müsst die kleinen Mitgliedstaaten pflegen. Das ist richtig. Der Bundeskanzler hat wirklich sehr viele Reisen gemacht.

Dr. Helmut Haussmann (FDP) [opposition]: Österreich war gut!

J.F: Mit Österreich besteht eine schöne Initiative in Bezug auf die Grenzregionen. Herr Haussmann, wären Sie dabei gewesen, hätten Sie richtig gestört, als wir da zusammengesessen haben.

H.H: Ja! Ja! (DE 2001.01.19)

${ }^{9}$ In the actual video recording, Turkey is not explicitly mentioned, but Pflüger says: "to exclude someone". 
J.F: Now the government is being admonished: You have to take care of the small countries. This is correct. The Chancellor has really made a lot of trips.

H.H: Austria was nice!

J.F: With Austria, there is a nice initiative regarding border regions. Mr. Haussmann, if you had been there, you would have really bothered while we all ate together.

H.H: Yes, yes!

(4) Birgit Homburger (FDP) [majority]: Wir haben uns hier in Deutschland als Koalition sogar ehrgeizigere Ziele gesetzt, Frau Schwall-Düren,

Dr. Eva Högl (SPD) [opposition]: Oh ja!

B.H: und wir werden die Erreichung dieser Ziele [...] entschieden voranbringen. (DE 2010.03.25)

B.H: We gave us even more ambitious goals in Germany as a coalition, Mrs. Schwall-Düren,

E.H: Oh yes!

B.H: and we will decisively commit ourselves to reach these goals [...].

In both cases, the interjection "Yes!" does not convey support from the opposition party. It is meant ironically, which the repetition "Yes, yes!" (3) and the double interjection "Oh yes!" in (4) suggest. The interrupting speakers are directly addressed in the utterance preceding the interjection, either as an individual MP (Haussmann) or as a representative of a party (Högl, who interrupts in (4), is a SPD member like Schwall-Düren, who is actually addressed). The interrupting speakers do not only react to the appeal, but also ironically demonstrate that they cast doubt on the previous utterance. Their disapproval arises either because the legitimate speaker attacked them, as in (3), where a small dialogue takes place, or because they do not believe in the propositional content "We gave us even more ambitious goals", as in (4).

Example (4) emblematically illustrates how interjections in parliamentary encounters target at multiple addressees. The double interjection "Oh yes!" is a response to the legitimate speaker, who is the main addressee in a dialogal context, but also a response to or in place of an in-group party member, who becomes an indirect addressee. The interjection is also aimed at target recipients of parliamentary discourse: the other MPs of the majority, and the broader audience composed of journalists, citizens, etc. The latters experience through the interjection the reactivity of the SPD, but also the party's ability to make criticism visible, even when they are not on the foreground, currently speaking. Interjections rarely appear spontaneously in parliamentary debates. On the contrary, the legitimate speaker expecting a reaction from the addressed MP triggers interjections. 


\section{ONTHE DIALOGICAL NATURE OF INTERJECTIONS}

The fact that interjections, despite their construed character, may be signs of an emergent dialogue between MPs raises the question of the dialogical nature of interjections. Leaving the specific domain of interjections as approval markers, I will investigate the relations between legitimate speaker and interrupting speaker. The cooccurrence of all types of interjections with terms of address (4.1) - and not only with interjections as approval markers (see 3.3) shows that interjections play a crucial part in parliamentary encounters. However, in most cases, MPs ignore interjections (4.2). When these markers lead to a discussion between MPs, they become what I call "ratified interjections" (4.3).

\subsection{INTERJECTIONS AS REACTIONS TO TERMS OF ADDRESS}

Following pattern occurs several times in the corpus: the legitimate speaker addresses one of his or her colleagues from the opposite parliamentary group to criticize him or her. This public condemnation usually triggers interjections from the addressed non-legitimate speaker. Interjections prototypically appear after the mention of a MP:

(5) Volker Kauder (CDU) [majority]: Herr Kollege Steinbrück, wir brauchen gerade von Ihnen keine Belehrungen

Peer Steinbrück (SPD) [opposition]: Doch!

V.K: zum Umgang in Europa. (DE 2012.10.18)

V.K: Dear Colleague Steinbrück, we do not need any lecture from you right now

P.S: You do!

V.K: about how to handle European issues.

The video recording shows that after intervening with the interjection Doch! (translated as the tag "You do!"), Steinbrück nods his head up and down, miming the interjection $j a$ ("yes") with a facial expression of boredom, as if confirming Kauder's blame. The gesture-speech analysis confirms the interpretation of $J a$ ! in (3) and (4) as ironic markers; often, in parliamentary debates, the addressed MP pretends to rule in favour of his or her opponent. Consequently, it disqualifies the attack because it implies that the aggression does not need to be properly countered.

In the following example, the legitimate speaker, Trittin, includes the interrupting speaker through a term of address ("Mr Kauder") as a response to the interjection Genau! ("Exactly!"). The interrupting speaker, Kauder, had been interrupted by a short intervention (Kurzintervention) a few minutes before and had defended himself against his opponent Gysi (Die Linke) by referring to the good school system they have in his constituency: 
(6) Jürgen Trittin (BÜNDNIS 90/DIE GRÜNEN) [opposition]: Ich habe jetzt gelernt, dass in Baden-Württemberg alle Schülerinnen und Schüler genau die Schule besuchen, die sie besuchen wollen.

Volker Kauder (CDU) [majority]: Genau!

J.T: Ich habe ein Weiteres gelernt, lieber Herr Kauder. (DE 2010.03.25)

J.T: I have now learned that all pupils in Baden-Württemberg can go to the school they want to.

V.K: Exactly!

J.T: I have also learned something else, Mr Kauder.

The interjection Genau! ("Exactly!") is not as trivial at it might seem, since it is a way to pursue the argumentation even when Kauder is not entitled to speak anymore. Reacting to the interjection, Trittin pretends to let Kauder introduce a second argument ("I have also learned something else"). The volitive component of interjections has already been noticed by Wierzbicka (1992:165), but what is striking in this case is that Genau! ("Exactly!") does not convey volition as such but is inferred as volitive from the pragmatic context ("I invite you to reconsider my situation and to acknowledge that I am right"). Thus, interjections range from minimal markers of attention or agreement to indicators of a dialogue despite the constraints of parliamentary settings, where only one MP speaks at a time.

Rosier already noticed in a corpus of literary works that interjections are often associated with terms of address (2000:28). Reactions to verbal aggressions belong to the staging of an authentic dialogue, in which MPs interact with each other. Ironic interjections of approval are an attempt to curve the perception of the target recipients by showing how the interrupting speaker, who has been blamed, challenges the point of view expressed by the legitimate speaker in a detached, synthetic manner.

\subsection{DISCARDED INTERJECTIONS}

Contrary to conversation, where turn exchange is the norm, parliamentary debates are strictly regulated, so that the legitimate speaker does not (need to) engage into a genuine dialogue with the interrupting speaker. Let's consider the 131 interjections of the corpus. Only 9 interjections out of $131(6,87 \%)$ lead to a verbal reaction of the interrupted speaker. Hence, the overall majority of interjections do not lead to any verbal reaction. It is less than for the four other types of interruptions apart from approval markers ${ }^{10}$ : attacks provoke reactions from the interrupted speakers in $24,14 \%$ of the cases; comments in $15,99 \%$; questions in $22,01 \%$; and requests in $24,59 \%$.

${ }^{10}$ Approval markers (including interjections, but not only) provoke reactions from the interrupted speakers in only $5,22 \%$ of the cases. 
These findings are expected, though, since interjections are so short that they are often inaudible or hard to attribute to someone. Moreover, it might be laborious to comment on an interjection. This is not to say that interjections have no argumentative nature as such. One difficulty for the analyst also lies in the fact that it is delicate to determine whether utterances from the legitimate speaker are answers or reactions to the previous interjections, or whether they were actually foreseen:

(7) Volker Kauder (CDU) [majority]: [...] Wir wollen den Bereich der erneuerbaren Energien ausbauen [...] Beifall bei der CDU/CSU und der FDP

Fritz Kuhn (BÜNDNIS 90/DIE GRÜNEN) [opposition]: Oje!

V.K: Wer den Menschen etwas anderes erzählt, sagt ihnen etwas Falsches.

F.K: Das ist doch Kauderwelsch! (DE 2010.03.25)

V.K: [...] We want to strengthen the field of renewable energies [...] Applause from the benches of CDU/CSU and FDP

F.K: Oh dear!

V.K: Whoever tells the people something else is lying.

F.K: This is only Kauder waffle!

The interjection Oje! ("Oh dear!") functions as a preparation of the more detailed critique "This is only Kauder waffle!" 11 . Kauder's utterance "Whoever tells the people something else is lying" is ambiguous, because one cannot know if it was intended before Kuhn's interjection, or if it is an indirect response to the dismay conveyed through the interjection "Oh dear!". Instead of actually addressing the interrupted speaker, the legitimate speaker provides a general statement embracing anyone who would say something else that he does, which shows that Kauder recorded the disagreement. Although interjections are discarded in the majority of cases, they can also lead to verbal reactions.

\subsection{RATIFIED INTERJECTIONS}

Despite their shortness and the fact that their meaning is wrapped in a nutshell, interjections also lead to explicit reactions. Thus, interjections can play a disruptive role and disturb the legitimate speaker in a speech that could have been a monologue otherwise. To show his or her ability to integrate interruptions into the ongoing discourse, the interrupted speaker has to pay attention to the precise content of interjections:

(8) Dr. Guido Westerwelle (FDP) [opposition]: Deshalb ist es besser, jetzt zu handeln, als zu warten, bis die Katastrophe da ist. Vorsorgendes Regieren ist besser, als später hinterherzulaufen. Darum wird es auch auf dem Gipfel

11 "Welsch" does not only mean "waffle" (aimless talk), but is regionally oriented: it is a designation against Swiss, French and South-German people; Kauder is elected in BadenWürttemberg. 
gehen. Beifall bei der FDP

Gerd Andres (SPD) [majority]: Kassandra!

G.W: Sie sagen „Kassandra“. Was bei Ihnen diskutiert wird, sind Konsumgutscheine. Das ist das, was Sie als Beitrag zur Krise vorschlagen. (DE 2008.12.04)

G.W: This is why it is better to act now, rather than to wait for the catastrophe. Preventive governance is better than running after the events. This is what the summit is about. Applause from the benches of FDP

G.A: Kassandra!

G.W: You are saying "Kassandra". You discuss consumption vouchers. This is what you offer as a contribution for the crisis.

(9) Joseph Fischer (BÜNDNIS 90/DIE GRÜNEN) [majority]: Leider gehört deren Mehrheit in Europa heute der EVP-Familie, also der konservativen Familie, Ihrer Familie, an.

Zuruf von der CDU/CSU [opposition]: Gott sei Dank!

J.F: Sie sagen: Gott sei Dank. - Dieser Beschluss war nur möglich, weil er einstimmig gefasst wurde, also mit den konservativen Stimmen. (DE 2003.06.26)

J.F: Unfortunately, the majority belongs today to the EPP family [European People's Party] that is to the Conservative family - your family.

Interruption from the Conservative party: Thank God!

J.F : You are saying: Thank God. - This decision was only possible because it was taken unanimously, that is with the Conservative votes.

These examples show how interjections are incorporated into the speech delivery of the legitimate speaker. This leads me to speak of "ratified interjections", deriving from Goffman's model (1981:9-10) of "ratified participant", divided into ratified participants "not specifically addressed by the speaker; and those ratified participants who are addressed, that is, oriented to by the speaker in a manner to suggest that his words are particularly for them, and that some answer is therefore anticipated from them, more so than from the other ratified participants". In (8) and (9), the interjection is simply recorded, reintegrated into the new utterance, but it is not properly reflected upon. It corresponds to the recognition of a "ratified participant", nevertheless not entitled to a felicitous answer.

The structure of examples (8) and (9) is strictly identical: the legitimate speaker repeats the interjection by associating it with the interrupting speaker ("You are saying"), but without commenting it or giving it a meaning. As for many secondary interjections, which are subjected to a grammaticalization process (Cuenca 2000:36), the meaning of "Kassandra!" and "Thank God!" is inferable from the semantics of the lexemes composing the locution. In "Thank God!", the religious semantic core (the appeal to God) has undergone semantic weakening, but the interjection still expresses a relief. The interjection "Kassandra" is a prophecy of doom, implying that the Liberal way of dealing 
with the European crisis is calamitous. As a secondary interjection derived from the mythological figure "Kassandra", the interjection is associated with a stable semantic content shared by the participants, probably independently from their knowledge of mythology due to the conventionalisation of the interjection.

Recalling the debate concerning the possibility for interjections to encode a semantic meaning, I argue that secondary interjections convey a conventionalised meaning partially encoded through grammaticalization. However, the semantic core is so weak that participants are insecure about the actual meaning conveyed by the speaker. Thus, they often only acknowledge the interjection, without enriching it with some particular pragmatic content. This interpretation is nevertheless based on very cautious speakers. In the following example, the opposite process is at stake:

(10) Joseph Fischer (BÜNDNIS 90/DIE GRÜNEN) [majority]: „Europa den Menschen vermitteln“, ich sehe, wir sind gerade heftig dabei. Neulich haben wir den Widerspruch Ihrer Fraktion in der Verfassungsfrage erlebt, Schäuble.

Dr. Wolfgang Schäuble (CDU) [opposition]: Aba!

J.F: Nicht ,aba“! (DE 2004.11.11)

J.F: "Communicating Europe", I see, we're on track. We have recently experienced the opposition of your parliamentary group with regard to the constitutional issue, Schäuble.

W.S: Aba!

J.F : Not "aba"!

The primary interjection "Aba!", due to its infrequency, can hardly be associated with any stable semantic content: in the reference dictionary Duden online (15.01.2017), it is described as a foreign word from Arabic referring to a coat, and the signification of the word as an interjection is not to be found. In Nübling's article (2004), it is not listed among primary interjections, even though the author recognises the list might be incomplete (2004:15). Since the interjection does not seem to be conventionally attested, the interrupted speaker has to build on the pragmatic context to draw on the interjection's meaning. Despite the unstable definition of the interjection, Fischer relies on his perception of the context to interpret the interjection as a critique - the interjection itself being triggered by a term of address, as we have already seen above -, which enables him to reject its propositional content. It does not mean that the semantic meaning of "Aba!" is not subject to variation, but it implies that in a particular socio-communicative context and from an addressee-oriented point of view, interjections can be denied, that is, the state of mind or feeling expressed through them can be held for impossible, untrue or illegitimate.

Interestingly, the ratification of interjections by interrupted speakers does not relate with the semantic status of the interjection. Speakers only acknowledged (without commenting) secondary interjections such as "Kassandra!" or "Thank 
God!", whose meaning is inferable from grammaticalization, but expounded on a primary interjection such as "Aba!", whose meaning is not attested. Joseph Fischer, foreign Foreign Minister and Vice Chancellor of Germany in the cabinet of Gerhard Schröder from 1998 to 2005, appears in two of the three examples. Fischer is particularly often interrupted: 83 times across the eighteen parliamentary debates, which is proportionally considerably more than other MPs. Out of these 83 interruptions, he reacts in 43 of the cases $(51,81 \%)$. Compared to the average reaction towards interruptions (17\%), this extremely high number shows that Fischer is well known for his tendency to react to interruptions. Thus, these analyses need to be confirmed by other occurrences coming from other Members of Parliament.

\section{CONCLUSION: INTERJECTIONS IN PARLIAMENTARY ENCOUNTERS}

This article dealt with interjections in a very specific interactional context: parliamentary debates at the German Bundestag. Although the results apply only to this particular setting, the analysis of the examples has confirmed many claims, but also leads to new perspectives: interjections play a special role in interrupting patterns. Contrary to other types of interruptions such as approval, attack, comment, question or request, interjections cannot unequivocally be associated with a semantic content. Nevertheless, several properties of interjections have emerged from the corpus analysis.

First, interjections are prototypical approval markers: 42 out of 131 interjections $(32,06 \%)$ have a support function. This figure nevertheless hides the fact that this support function often appears between Members of Parliament from opposite parliamentary groups. In those cases, interjections function as ironic markers and do not convey agreement. Apart from the actual meaning of interjections, interjections have proved to be signals towards the addressees and target recipients of parliamentary talk. Interjections contribute to the staging of a dialogue in the parliament. When the legitimate speaker addresses another MP, a short interruption though an interjection enables the MP to record the address as well as to contest what is being said about him or her. On the other hand, and despite their shortness, interjections also trigger reactions from the legitimate speakers, although very rarely compared to other sorts of interruptions.

Following Padilla Cruz (2009b:242), "[t]his paper does not aim to offer a definitive answer to the question of whether or not interjections really encode some conceptual content." Rather, I retain the idea of a continuum: "interjections may move along a continuum including some more conceptual items, other less conceptual items and items that do not encode any conceptual content at all" (Padilla Cruz 2009b:242). The last occurrences have demonstrated that interjections highly depend on the speakers interpretation, "so that there would 
be speakers for whom some interjections may be unequivocally associated with some specific concepts and others for whom the same interjections may be linked to different concepts or no concepts at all" (Padilla Cruz 2009b:242).

The fact that interjections seem to be understood the same way amongst speakers of various political parties over the years tends to show that the Bundestag works as a community of practice (Harris 2001:453) relying on mutual engagement, a joint negotiated enterprise, a shared repertoire of negotiable resources accumulated over time (Wenger 1998:73). In this sense, decoding interjections is based on shared knowledge between participants who are used to playing along the same rules. Interjections in adversarial political context do not solely express a feeling or a state of mind. Rather, one has to consider their argumentative nature to understand their pragmatic changes of meaning (for instance, the ironic connotation of approving interjections in certain contexts) and the fact that they can be contested, even when their semantic core remains unclear. 


\section{REFERENCES}

Ameka, F. (1992a), «Interjections: The universal yet neglected part of speech », Journal of Pragmatics 18, 2. 101-118. doi:10.1016/0378-2166(92)90048-G.

Ameka, F. (1992b), « The meaning of phatic and conative interjections », Journal of Pragmatics 18, 2. 245-271. doi:10.1016/0378-2166(92)90054-F.

Bevitori, C. (2004), « Negotiating conflict. Interruptions in British and Italian parliamentary debates », in Cross-Cultural Perspectives on Parliamentary Discourse, Amsterdam/Philadelphia : John Benjamins Publishing, 87-109.

Bonnafous, S. \& Desmarchelier D. (1999), «Quand les députés coupent le "RESEDA.” », Mots 60, 1. 93-109. doi:10.3406/mots.1999.2166.

Burkhardt, A. (2004), Zwischen Monolog und Dialog. Zur Theorie, Typologie und Geschichte des Zwischenrufs im deutschen Parlamentarismus. Tübingen : Max Niemeyer Verlag.

Carbó, T. (1992), « Towards an Interpretation of Interruptions in Mexican Parliamentary Discourse (1920-60) », Discourse \& Society 3, 1, 25-45.

Caron-Pargue, J. \& Caron J. (2000), « Les interjections comme marqueurs du fonctionnement cognitif », Cahiers de praxématique 34, 51-76.

Cormenin, L. (1837), Etudes sur les orateurs parlementaires, Paris : Pagnerre.

Cuenca, M-J. (2000), « Defining the indefinable? Interjections ». Syntaxis 3, 29-44.

Ducrot, O. (ed.) (1980), Les mots du discours, Paris : Éditions de Minuit.

Ehlich, K. (1986), Interjektionen, Berlin/New York : Walter de Gruyter.

Goffman, E. (1981), Forms of Talk, Philadelphia : University of Pennsylvania Press.

Harris, S. (2001), « Being Politically Impolite: Extending Politeness Theory to Adversarial Political Discourse », Discourse \& Society 12, 4, 451-472. doi:10.1177/095 7926501012004003.

Hitzler, R. (1990), « Die Politik des Zwischenrufs: zu einer kleinen parlamentarischen Form », Zeitschrift für Parlamentsfragen 21, 4, 619-630.

Kühn, P. (1983), « Der parlamentarische Zwischenruf als mehrfachadressierte Sprachhandlung », in Sprache, Diskurs und Text, Tübingen : Mouton de Gruyter, 239251.

Meng, K. \& Schrabback S. (1999), « Interjections in adult-child discourse: The cases of German HM and NA », Journal of Pragmatics 31, 10. 1263-1287. doi:10.1016/ S0378-2166(98)00105-2.

Nübling, D. (2004), « Die prototypische Interjektion: Ein Definitionsvorschlag », Zeitschrift für Semiotik 26, 1-2, 11-46. 
Olschewski, A. (2000), « Die Verschriftung von Parlamentsdebatten durch die stenographischen Dienste in Geschichte und Gegenwart », in Sprache des deutschen Parlamentarismus. Studien zu 150 Jahren parlamentarischer Kommunikation, Wiesbaden : Springer, 336-353.

Padilla Cruz, M. (2009a), « Towards an Alternative Relevance-Theoretic Approach to Interjections », International Review of Pragmatics 1, 1. 182-206. doi:10.1163/187731009X455884.

Padilla Cruz, M. (2009b), « Might Interjections Encode Concepts? More Questions than Answers », Lodz Papers in Pragmatics 5, 2. 241-270. doi:10.2478/v10016-0090015-9.

Rosier, L. (2000), «Interjection, subjectivité, expressivité et discours rapporté à l'écrit : petits effets d'un petit discours », Cahiers de praxématique 34, 19-50.

Sacks, H., Schlegoff, E. \& Jefferson, G. (1974), « A simplest systematics for the organization of turn-taking for conversation », Language 50, 696-735.

Shenhav, S. (2008), « Showing and telling in parliamentary discourse: the case of repeated interjections to Rabin's speeches in the Israeli parliament », Discourse \& Society 19, 2, 223-255. doi:10.1177/0957926507085953.

Van der Valk, I. (2000), « Interruptions in French debates on immigration », in The Semiotics of Racism. Approaches in Critical Discourse Analysis, Vienna : Passagen-Verlag, 105-128.

Wenger, E. (1998), Communities of Practice. Learning, Meaning, and Identity. Cambridge : Cambridge University Press.

Wharton, T. (2000), « Interjections, language, and the "showing/saying" continuum », 173-215. Université de Paris. doi:10.1075/pc.11.1.04wha.

Wierzbicka, A. (1992), « The semantics of interjection », Journal of Pragmatics 18, 2 , 159-192. doi:10.1016/0378-2166(92)90050-L.

Wilkins, D. (1992), « Interjections as deictics », Journal of Pragmatics 18, 2, 119-158. doi:10.1016/0378-2166(92)90049-H.

Zima, E, Brône, G. \& Feyaerts, K. (2010), « Patterns of interaction in Austrian parliamentary debates. On the pragmasemantics of unauthorized interruptive comments », in European Parliaments under Scrutiny. Discourse strategies and interaction practices, Amsterdam/Philadelphia : John Benjamins, 135-164. 